\title{
Carbon, oxygen and biological productivity in the Southern Ocean in and out the Kerguelen plume: CARIOCA drifter results
}

\author{
L. Merlivat, J. Boutin, and F. d'Ovidio \\ Sorbonne Universités (UPMC, Univ Paris 06)-CNRS-IRD-MNHN, LOCEAN Laboratory, 4 place Jussieu, \\ 75005 Paris, France
}

Correspondence to: L. Merlivat (merlivat@ locean-ipsl.upmc.fr)

Received: 13 November 2014 - Published in Biogeosciences Discuss.: 9 December 2014

Revised: 30 April 2015 - Accepted: 12 May 2015 - Published: 9 June 2015

\begin{abstract}
The Kerguelen Plateau region in the Indian sector of the Southern Ocean supports annually a large-scale phytoplankton bloom which is naturally fertilized with iron. As part of the second Kerguelen Ocean and Plateau compared Study expedition (KEOPS2) in austral spring (OctoberNovember 2011), one CARbon Interface OCean Atmosphere (CARIOCA) buoy was deployed east of the Kerguelen Plateau. It drifted eastward downstream along the Kerguelen plume. Hourly surface measurements of $p \mathrm{CO}_{2}, \mathrm{O}_{2}$ and ancillary observations were collected between 1 November 2011 and 12 February 2012 with the aim of characterizing the spatial and temporal variability of the biological net community production, NCP, downstream the Kerguelen Plateau, assessing the impact of iron-induced productivity on the biological inorganic carbon consumption and consequently on the $\mathrm{CO}_{2}$ flux exchanged at the air-sea interface. The trajectory of the buoy up to mid-December was within the longitude range $72-83^{\circ} \mathrm{E}$, close to the polar front and then in the polar frontal zone, PFZ, up to $97^{\circ}$ E. From 17 November to 16 December, the buoy drifted within the Kerguelen plume following a filament carrying dissolved iron, $\mathrm{DFe}$, for a total distance of $700 \mathrm{~km}$. In the first part of the trajectory of the buoy, within the iron plume, the ocean surface waters were always a sink for $\mathrm{CO}_{2}$ and a source for $\mathrm{O}_{2}$, with fluxes of respective mean values equal to $-8 \mathrm{mmol} \mathrm{CO}_{2}$ and $+38 \mathrm{mmol} \mathrm{O}_{2} \mathrm{~m}^{-2} \mathrm{~d}^{-1}$. To the east, as the buoy escaped the iron-enriched filament, the fluxes were in the opposite direction, with respective mean values of $+5 \mathrm{mmol} \mathrm{CO}_{2}$ and $-48 \mathrm{mmol} \mathrm{O}_{2} \mathrm{~m}^{-2} \mathrm{~d}^{-1}$. These numbers clearly indicate the strong impact of biological processes on the biogeochemistry in the surface waters within the Kerguelen plume in November-mid-December, while it is undetectable to the east in the PFZ from mid-
\end{abstract}

December to mid-February. While the buoy follows the Feenriched filament, simultaneous observations of dissolved inorganic carbon (DIC) and dissolved oxygen $\left(\mathrm{O}_{2}\right)$ highlight biological events lasting from 2 to 4 days. Stoichiometric ratios, $\mathrm{O}_{2} / \mathrm{C}$, between 1.1 and 1.4 are observed indicating new and regenerated production regimes. NCP estimates range from 60 to $140 \mathrm{mmol} \mathrm{C} \mathrm{m}^{-2} \mathrm{~d}^{-1}$.

\section{Introduction}

The Southern Ocean is a key region for the global carbon cycle and the climate system. It accounts for about $25-30 \%$ of the anthropogenic carbon uptake by the ocean. The Southern Ocean (south of about $30^{\circ} \mathrm{S}$ ) is found to be a sink area for atmospheric $\mathrm{CO}_{2}$ in atmospheric or ocean inversion models (Friedlingstein et al., 2006; Gruber et al., 2009) as well as in data-based approaches (Metzl et al., 1999; Takahashi et al., 2009). However, it represents a sink for atmospheric $\mathrm{CO}_{2}$ whose strength and future evolution are debated (Le Quéré et al., 2010; Lenton et al., 2013). Despite its importance, the Southern Ocean remains the region where uncertainties regarding the air-sea $\mathrm{CO}_{2}$ flux and the carbon budget are the highest (e.g., Gruber et al., 2009). This remote part of the global ocean is hardly accessible in winter, leading to a very sparse spatiotemporal coverage of observations, including measurements of surface $p \mathrm{CO}_{2}$. Undersampling biases are aggravated by the high variability which characterizes this oceanic region over a wide range of temporal and spatial scales. Quantification of the impacts of thermodynamics, biology and physics on the sea surface partial pressure of $\mathrm{CO}_{2}$ $\left(p \mathrm{CO}_{2}\right)$ is a necessary step to understand the processes reg- 
ulating the ocean-atmosphere exchange of $\mathrm{CO}_{2}$ and help to overcome the unresolved spatiotemporal variability effects.

The magnitude of the gradient of $p \mathrm{CO}_{2}$ between the atmosphere and the surface ocean depends on the relative contribution in the ocean mixed layer of the dynamic transport, the thermodynamics and the biological activity. Biological net community production, NCP, decreases sea surface $p \mathrm{CO}_{2}$. In high-nutrient, low-chlorophyll (HNLC) regions , including the Southern Ocean, more than 2 decades of intense research have confirmed that increasing iron supply stimulates primary production (Boyd et al., 2007; Blain et al., 2008). Large and persistent phytoplankton blooms develop annually in the vicinity of subantarctic islands (Blain et al., 2007; Borrione and Schlitzer, 2013; Pollard et al., 2009) due to natural iron supply. The results of field studies in the vicinity of Crozet and Kerguelen islands have clearly highlighted the crucial role of $\mathrm{Fe}$ in natural ecosystems and demonstrate the stimulation of the biological carbon pump. In February 2005, the KErguelen Ocean and Plateau compared Study expedition, KEOPS1, focused on the high-productivity area of the Kerguelen Islands during the peak and decline of the bloom (Blain et al., 2007). The results emphasized the opportunity of studies on the Kerguelen Plateau to investigate the functioning of the biological carbon pump in a naturally iron-fertilized region. The KEOPS 2 project in OctoberNovember 2011, designed to improve the spatial and temporal coverage of the Kerguelen region, was carried out in austral spring to document the early stages of the bloom and to complement results of KEOPS1.

As part of KEOPS2, a CARbon Interface OCean Atmosphere (CARIOCA) buoy was launched, drifted eastward close to the polar front then entered the polar frontal zone, PFZ. NCP is deduced from high frequency $p \mathrm{CO}_{2}$ measurements made in November-December along the trajectory of the drifter. The aim of the present work is to provide an indepth look of the extent of the iron seeding downstream the plateau during the end of the spring, its effect on the production of organic carbon and its control of the $\mathrm{CO}_{2}$ air-sea flux.

\section{Data and methods}

\subsection{Site description}

A CARIOCA buoy was deployed as part of the KEOPS2 expedition that took place from 9 October to 29 November 2011, in the Indian sector of the Southern Ocean in the vicinity of the Kerguelen Islands. It was deployed on 1 November 2011 over the Kerguelen Plateau and drifted eastward downstream within the Kerguelen plume. Up to 12 February 2012 , its $\sim 1800 \mathrm{~km}$ trajectory followed the polar front closely, entering the polar frontal zone on 16 December 2011 (Fig. 1). The buoy acquired data in the $72-75^{\circ} \mathrm{E}$ longitude range of the intensive KEOPS2 field

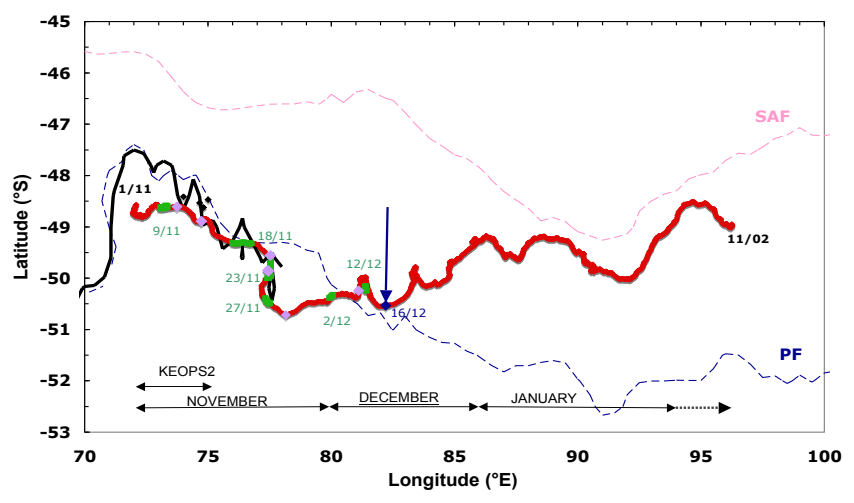

Figure 1. Trajectory followed by the CARIOCA drifter from 1 November 2011 to 12 February 2012 (red line). The green dots and numbers indicate the location and date where the data indicate a large signature of biological effects. The grey diamonds indicate high isolated salinity anomalies. The buoy enters the polar frontal zone at the location of the blue arrow. The pink dotted line represents the location of the subantarctic front, the blue dashed line shows the location of the polar front (Park and Vivier, 2009, 2011) and the black line, the location of the polar front based on KEOPS2 observations, PF_Park (Park et al., 2014). The black dots indicate the location of the KEOPS2 stations (TEW-7, TEW-8, NPF-L) close to the PF.

campaign from 1 to 15 November 2011 and then was advected downstream within the Kerguelen plume later in the season.

\subsection{Buoy measurements}

The CARIOCA buoy was equipped with a $\mathrm{CO}_{2}$ sensor (Copin-Montegut et al., 2000; Hood and Merlivat, 2001) and an Anderaa F3835 optode to measure dissolved $\mathrm{O}_{2}$ (Lefèvre and Merlivat, 2012). The partial pressure of $\mathrm{CO}_{2}\left(p \mathrm{CO}_{2}\right)$, dissolved oxygen concentration $\left(\mathrm{O}_{2}\right)$, sea surface temperature (SST) and sea surface salinity (SSS) were measured at a depth of $2 \mathrm{~m}$ on an hourly basis. Atmospheric pressure and wind speed were measured at a height of $2 \mathrm{~m}$, which were subsequently corrected to $10 \mathrm{~m}$ height values. Collected data have been transmitted by the buoy in realtime via the Advanced Research and Global Observation Satellite (Argos) data network.

Strictly speaking, the $\mathrm{CO}_{2}$ sensor measures the fugacity of $\mathrm{CO}_{2}, f \mathrm{CO}_{2}$, which is not identical to $p \mathrm{CO}_{2}$ owing to the non-ideal nature of the $\mathrm{CO}_{2}$ gas (Dickson et al., 2007). In the range of SST of our study, the difference between $p \mathrm{CO}_{2}$ and $f \mathrm{CO}_{2}$ is close to $1.4 \mu \mathrm{atm}$, which is within the instruments $3 \mu \mathrm{atm}$ absolute error. Accordingly, we will approximate $f \mathrm{CO}_{2}$ as being equal to $p \mathrm{CO}_{2}$ within this study.

Alkalinity, Alk $\left(\mu \mathrm{mol} \mathrm{kg}^{-1}\right)$, is computed from SST and sea surface salinity, SSS, using the alkalinity-temperaturesalinity relationship proposed by Lee et al. (2006) for the Southern Ocean. Dissolved inorganic carbon, DIC $\left(\mu \mathrm{mol} \mathrm{kg}^{-1}\right)$, is derived from $p \mathrm{CO}_{2}$, Alk, SST and SSS us- 
ing the $\mathrm{CO}_{2}$ dissociation constants of Mehrbach et al. (1973) as refitted by Dickson and Millero (1987) and solubility from Weiss (1974). An accuracy of $10.5 \mu \mathrm{mol} \mathrm{kg}{ }^{-1}$ was estimated as a result of the combined uncertainties linked to the dissociation constants, the accuracy of $p \mathrm{CO}_{2}$ measurements and the uncertainty of the alkalinity derived from the relationship proposed by Lee et al. (2006) (Boutin et al., 2008). The relative precision of successive DIC values is expected to be $0.5 \mu \mathrm{mol} \mathrm{kg}^{-1}$ (Boutin et Merlivat, 2009; Merlivat et al., 2015).

The oxygen optode measurements were calibrated initially in the laboratory prior to deployment using a 0 and $100 \%$ oxygen reference points. During the KEOPS2 cruise, the optode data were subsequently calibrated against the oxygen Winkler measurements made with an accuracy of $0.2 \%$ (D. Lefèvre, personal communication, 2012). A constant offset of $13.6 \mu \mathrm{mol} \mathrm{kg} \mathrm{kg}^{-1}$ between the two techniques was found. Johnson (2010) compared the optode measurements recorded at a time series off Monterey Bay, California, with shipboard measurements made using the Winkler method. He found an offset between the two techniques, which remained constant over the 5-month period of his record. Therefore, we simply apply an offset of $13.6 \mu \mathrm{mol} \mathrm{kg} \mathrm{k}^{-1}$ to correct the optode data. Oxygen saturation, $\mathrm{O}_{2}$ sat (in $\mu \mathrm{mol} \mathrm{kg} \mathrm{kg}^{-1}$ ) is calculated using the equation of Garcia and Gordon (1992). The degree of $\mathrm{O}_{2}$ saturation (\%) is given by

$\% \mathrm{O}_{2}$ sat $=\left(\left[\mathrm{O}_{2}\right] /\left[\mathrm{O}_{2}^{\mathrm{sat}}\right]\right) \times 100$.

\subsection{Calculation of air-sea fluxes of $\mathrm{CO}_{2}$ and $\mathrm{O}_{2}$}

The hourly air-sea $\mathrm{CO}_{2}$ flux, $F_{\mathrm{CO}_{2}}\left(\mathrm{mmolm}{ }^{-2} \mathrm{~d}^{-1}\right)$, is derived from wind speed, the air-sea gradient in $p \mathrm{CO}_{2}$ and the gas transfer velocity (Boutin et al., 2008; Merlivat et al., 2015), following:

$F_{\mathrm{CO}_{2}}=k_{\mathrm{CO}_{2}} \alpha_{\mathrm{CO}_{2}}\left(p \mathrm{CO}_{2 \text { sea }}-p \mathrm{CO}_{2 \mathrm{~atm}}\right)$,

where $\alpha_{\mathrm{CO}_{2}}$ is the solubility of $\mathrm{CO}_{2}$ (Weiss, 1974), $p \mathrm{CO}_{2}$ sea the partial pressure of $\mathrm{CO}_{2}$ in seawater ( $\mu$ atm), $p \mathrm{CO}_{2} \mathrm{~atm}$ the partial pressure of $\mathrm{CO}_{2}$ in the atmosphere ( $\mu$ atm) and $k_{\mathrm{CO}_{2}}\left(\mathrm{~cm} \mathrm{~h}^{-1}\right)$ is the gas transfer velocity for $\mathrm{CO}_{2} \cdot p \mathrm{CO}_{2} \mathrm{~atm}$ is computed from the monthly molar fraction $x \mathrm{CO}_{2}$ at the Macquarie Island atmospheric station (NOAA/ESRL Global Monitoring Division (http://esrl.noaa.gov/gmd/ccgg/iadv)), the water vapor pressure of Weiss and Price (1980) and the atmospheric pressure recorded on the drifter.

Injection of air bubbles below the air-water interface is neglected for the calculation of the $\mathrm{CO}_{2}$ flux but this contribution to the flux can be relatively important for oxygen. The equation of the $\mathrm{O}_{2}$ flux is then given by

$F_{\mathrm{O}_{2}}=k_{\mathrm{O}_{2}}\left(\left[\mathrm{O}_{2}\right]-\left[\mathrm{O}_{2 \text { sat }}\right]\right)-F_{\text {bub }}$

where $k_{\mathrm{O}_{2}}$ is the gas transfer velocity for $\mathrm{O}_{2}$ and $F_{\text {bub }}$ is the contribution of air bubbles using the formula given by Woolf and Thorpe (1991):

$F_{\text {bub }}=k_{\mathrm{O}_{2}} 0.01\left(U / U_{0}\right)^{2}\left[O_{2 \mathrm{sat}}\right]$,

with $U$ the wind speed at $10 \mathrm{~m}$ height in $\mathrm{ms}^{-1}$ and $\mathrm{U}_{0}$ a model-derived constant wind speed value equal to $9 \mathrm{~ms}^{-1}$ to compute bubbles $\mathrm{O}_{2}$ air-sea flux.

The total oxygen flux becomes

$F_{\mathrm{O}_{2}}=k_{\mathrm{O}_{2}}\left(\left[\mathrm{O}_{2}\right]-\left[O_{2 \text { sat }}\right]\left(1+1.2310^{-4} U^{2}\right)\right)$.

It results from this equation that the flux is positive when there is outgassing to the atmosphere.

For both $\mathrm{CO}_{2}$ and $\mathrm{O}_{2}$, the gas transfer velocity is calculated using the formula of Sweeney et al. (2007):

$k=0.27 U^{2}(660 / S c)^{0.5}$,

where $S c$ is the Schmidt number, $S c_{\mathrm{CO}_{2}}$, for $\mathrm{CO}_{2}$ or $S c_{\mathrm{O}_{2}}$ for $\mathrm{O}_{2}$ (Wanninkhof, 1992) and $U$ the $10 \mathrm{~m}$ wind speed.

\subsection{Calculation of in situ carbon and oxygen biological production}

Carbon net community production, $\mathrm{NCP}_{\mathrm{C}}$, has been previously derived from drifting CARIOCA buoy measurements, by looking at day-to-day evolution of DIC at dawn provided that daily cycles of DIC in phase with the ones expected from biological activity are observed (Merlivat et al., 2009, 2015; Boutin and Merlivat, 2009). In addition, in case $\mathrm{O}_{2}$ is measured, it is possible to simultaneously estimate $\mathrm{NCP}$ from $\mathrm{O}_{2}$ day-to-day evolution, $\mathrm{NCP}_{\mathrm{O}_{2}}$ (Lefèvre and Merlivat, 2012). The method relies on hourly measurements of SST, SSS, $p \mathrm{CO}_{2}$ and $\mathrm{O}_{2}$ to estimate in situ biological production from unattended platforms using a non-intrusive method. During the daylight period, photosynthesis, respiration and air-sea exchange are mechanisms responsible for the change in DIC and $\mathrm{O}_{2}$ recorded at $2 \mathrm{~m}$ depth. If no significant change in salinity is observed, the processes of advection and mixing, and thus DIC and $\mathrm{O}_{2}$ fluxes through the base of the mixed layer, $h$, are assumed to be negligible. Depending on atmospheric forcing, a warm diurnal layer, $h^{*}$, can form during daylight (Merlivat et al., 2009). In this surface layer, of depth $h^{*}$, from sunrise to sunset, due to combined effect of photosynthesis and respiration, DIC generally decreases and $\mathrm{O}_{2}$ generally increases; they reach minimum, DICmin, and maximum, $\mathrm{O}_{2}$ max, values at the end of the day. At night, as a result of respiration and of the mixing between the warm layer and the mixed layer, DIC increases and $\mathrm{O}_{2}$ decreases; they reach maximum, DIC max, and minimum, $\mathrm{O}_{2}$ min, values at the end of natural convection. NCP is derived from the day-to-day change of DICmax and $\mathrm{O}_{2} \mathrm{~min}$, after removing the contribution of the air-sea fluxes. Contribution of biological activity (photosynthesis plus respiration) during daylight is derived from DICmax-DICmin, and $\mathrm{O}_{2}$ min- $\mathrm{O}_{2}$ max after removing the contribution of the air-sea fluxes. Figure 2 shows SST, DIC and $\mathrm{O}_{2}$ over a 4-day period, 
Table 1. Difference between the extrema of DIC and $\mathrm{O}_{2}$ measured in the warm surface layer (columns 4 and 6). In bold, mean values of DIC and $\mathrm{O}_{2}$ changes over consecutive mornings (columns 5 and 7), $\mathrm{CO}_{2}$ and $\mathrm{O}_{2}$ air-sea flux (columns 8 and 9) are shown.

\begin{tabular}{|c|c|c|c|c|c|c|c|c|}
\hline Date & $\begin{array}{c}\text { Latitude } \\
\text { Longitude } \\
2\end{array}$ & $\begin{array}{c}\mathrm{SST} \\
{ }^{\circ} \mathrm{C} \\
3\end{array}$ & $\begin{array}{c}\mathrm{DIC}_{\min }-\mathrm{DIC}_{\max } \\
\mu \mathrm{mol} \mathrm{kg} \\
4\end{array}$ & $\begin{array}{c}\mathrm{dDIC}_{\max } / \mathrm{d} t \\
\mu \operatorname{mol~kg}^{-1} \\
5\end{array}$ & $\begin{array}{c}\mathrm{O}_{2 \max }-\mathrm{O}_{2 \min } \\
\mu \mathrm{mol} \mathrm{kg}-1 \\
6\end{array}$ & $\begin{array}{c}\mathrm{dO}_{2 \min } / \mathrm{d} t \\
\mu \mathrm{mol} \mathrm{kg}^{-1} \\
7\end{array}$ & $\begin{array}{c}F_{\mathrm{CO}_{2}} \\
\mathrm{mmolm}^{-2} \mathrm{~d}^{-1} \\
8\end{array}$ & $\begin{array}{c}F_{\mathrm{O}_{2}} \\
\mathrm{mmol} \mathrm{m}^{-2} \mathrm{~d}^{-1} \\
9\end{array}$ \\
\hline $18 \mathrm{Nov}$ & $49.3^{\circ} \mathrm{S}, 76.4^{\circ} \mathrm{E}$ & 4.2 & $-6.46 \pm 1.00$ & & $7.19 \pm 1.00$ & & & \\
\hline 23-25 Nov & $50.1^{\circ} \mathrm{S}, 77.4^{\circ} \mathrm{E}$ & 4.3 & & $-4.72 \pm 0.23$ & & $3.74 \pm 0.54$ & -8.21 & 42.9 \\
\hline $23 \mathrm{Nov}$ & & & $-11.50 \pm 1.00$ & & $9.77 \pm 1.00$ & & & \\
\hline 24 Nov & & & $-10.09 \pm 1.00$ & & $11.41 \pm 1.00$ & & & \\
\hline 26-28 Nov & $50.4^{\circ} \mathrm{S}, 77.3^{\circ} \mathrm{E}$ & 4.4 & & $-4.22 \pm 0.85$ & & $3.90 \pm 1.01$ & -5.83 & 38.5 \\
\hline 27 Nov & & & $-9.35 \pm 1.00$ & & $8.39 \pm 1.00$ & & & \\
\hline 30 Nov-4 Dec & $50.4^{\circ} \mathrm{S}, 79.8^{\circ} \mathrm{E}$ & 4.5 & & $-1.76 \pm 0.43$ & & $1.71 \pm 0.32$ & -9.13 & 47.4 \\
\hline $30 \mathrm{Nov}$ & & & $-8.50 \pm 1.00$ & & $6.17 \pm 1.00$ & & & \\
\hline $1 \mathrm{Dec}$ & & & $-5.79 \pm 1.00$ & & $5.73 \pm 1.00$ & & & \\
\hline $2 \mathrm{Dec}$ & & & $-7.80 \pm 1.00$ & & $7.25 \pm 1.00$ & & & \\
\hline 11-13 Dec & $50.2^{\circ} \mathrm{S}, 81.4^{\circ} \mathrm{E}$ & 4.6 & & $-2.10 \pm 0.65$ & & & -10.49 & 61.0 \\
\hline
\end{tabular}

30 November-4 December 2011. The mean increase of SST equal to $0.044^{\circ} \mathrm{C} \mathrm{d}^{-1}$, superimposed on daily cycles of SST, indicates a stratification of the mixed layer over this 4-day period. No change of salinity is measured (not shown). Thus, the changes in DIC and $\mathrm{O}_{2}$ observed during the 4 days were only driven by biological processes allowing the computation of NCP. The carbon and oxygen mass balance, either in the daytime interval during the development of the warm layer, $h^{*}$, or over a 1-day time interval in the mixed layer, $h$, result in the two following equations:

$$
\begin{aligned}
& \left(\frac{\Delta \mathrm{DIC}}{\Delta t}\right)_{\text {measured }}=\left(\frac{\Delta \mathrm{DIC}}{\Delta t}\right)_{\text {bio }}+\left(\frac{\Delta \mathrm{DIC}}{\Delta t}\right)_{\text {air-sea }}, \\
& \left(\frac{\Delta \mathrm{O}_{2}}{\Delta t}\right)_{\text {measured }}=\left(\frac{\Delta \mathrm{O}_{2}}{\Delta t}\right)_{\text {bio }}+\left(\frac{\Delta \mathrm{O}_{2}}{\Delta t}\right)_{\text {air-sea }} .
\end{aligned}
$$

NCP integrated over the mixed layer is given by

$\mathrm{NCP}_{\mathrm{c}}=\rho h \frac{\Delta \mathrm{DIC} \max }{\Delta t}+F_{\mathrm{CO}_{2}}$,

$\mathrm{NCP}_{\mathrm{O}_{2}}=\rho h \frac{\Delta \mathrm{O}_{2 \min }}{\Delta t}+F_{\mathrm{O}_{2}}$,

where $F_{\mathrm{CO}_{2}}$ and $F_{\mathrm{O}_{2}}$ are the air-sea $\mathrm{CO}_{2}$ and $\mathrm{O}_{2}$ flux ( $\mathrm{mmol} \mathrm{m} \mathrm{m}^{-2} \mathrm{~d}^{-1}$ ), positive when there is outgassing to the atmosphere. $h(\mathrm{~m})$ is the depth of the mixed layer, $\rho\left(\mathrm{kg} \mathrm{m}^{-3}\right)$ is the density of seawater and $\Delta \mathrm{DIC}_{\max } / \Delta t$ and $\Delta \mathrm{O}_{2 \min } / \Delta t$ $\left(\mu \mathrm{mol} \mathrm{kg} \mathrm{kg}^{-1} \mathrm{~d}^{-1}\right)$ are the change of DIC $\left(\mathrm{O}_{2}\right)$ between two consecutive maxima (minima).

Between two consecutive mornings, at the end of nocturnal convection,

$\left(\frac{\Delta \mathrm{DIC}}{\Delta t}\right)_{\text {air-sea }}$ and $\left(\frac{\Delta \mathrm{O}_{2}}{\Delta t}\right)_{\text {air-sea }}$ are respectively equal to $F_{\mathrm{CO}_{2}} / h$ and $F_{\mathrm{O}_{2}} / h$ (where $h$ is the mixed layer depth, MLD). During the daily stratification period, the diurnal mixed layer thickness decreases from $\mathrm{h}$ to $h^{*}$ when DIC is minimum and $\mathrm{O}_{2}$ is maximum. We make the assumption that it varies linearly from $h$ to $h^{*}$ in order to compute the hourly values of the air-sea flux contribution, $(F / h)_{i}$, which then are added over the daily stratification period. We assume that
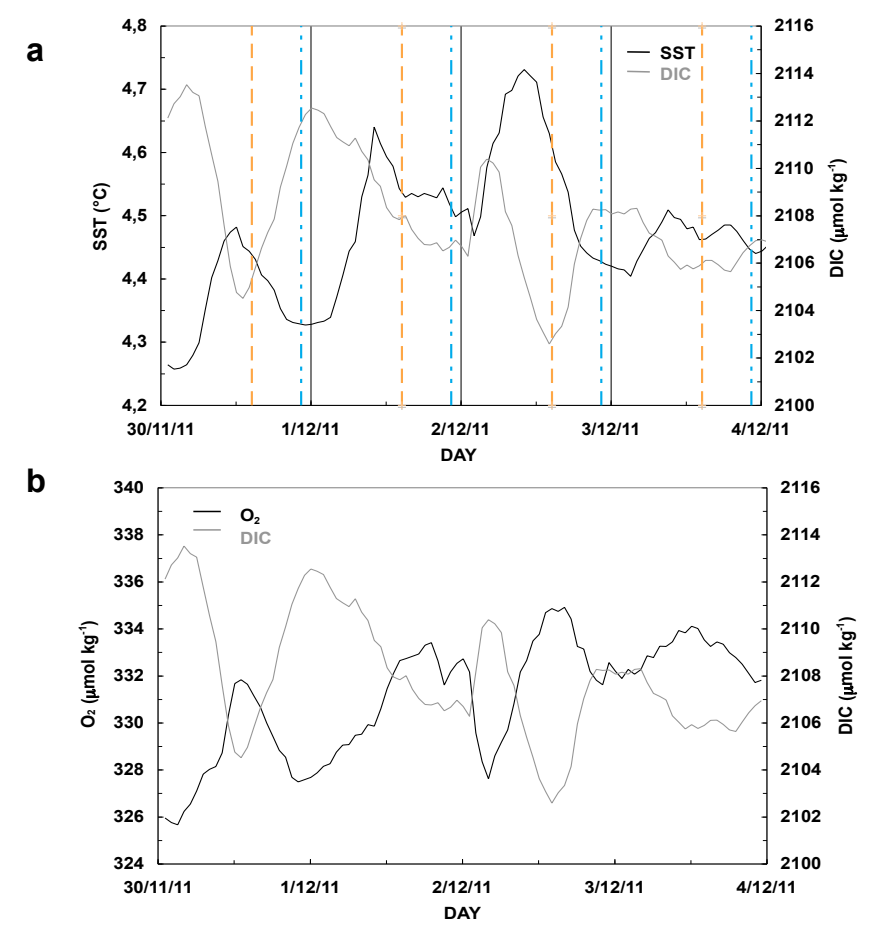

Figure 2. Diurnal cycles of SST, DIC and $\mathrm{O}_{2}$ from 30 November to 4 December 2011. (a) SST $\left({ }^{\circ} \mathrm{C}\right)$ (black, left vertical axis) and DIC ( $\left.\mu \mathrm{mol} \mathrm{kg}^{-1}\right)$ (grey, right vertical axis). The vertical dashed lines indicate the time of sunrise (blue) and sunset (orange). (b) $\mathrm{O}_{2}$ $\left(\mu \mathrm{mol} \mathrm{kg}{ }^{-1}\right)$ (black, left vertical axis) and DIC (grey, right vertical axis).

the minimum depth of the diurnal mixed layer, $h^{*}$, at the end of the production period is equal to the sampling depth $2 \mathrm{~m}$. A mixed layer depth equal to $20 \mathrm{~m}$ has been adopted based on observations made during the KEOPS2 field campaign under conditions similar to those encountered by the buoy. We will discuss later the uncertainties related to this choice. 
Table 2. Biological changes (columns 2 and 4) and air-sea flux changes (columns 3 and 5) of DIC and $\mathrm{O}_{2}$. Calculated values of NCP carbon and NCP oxygen (columns 6 and 7). In bold, mean values over consecutive mornings.

\begin{tabular}{|c|c|c|c|c|c|c|}
\hline Date & $\begin{array}{c}\mathrm{dDIC}_{\mathrm{bio}} \\
\mu \mathrm{mol} \mathrm{kg}{ }^{-1} \\
2\end{array}$ & $\begin{array}{l}\mathrm{dDIC}_{\text {air-sea }} \\
\mu \mathrm{mol} \mathrm{kg}^{-1} \\
3\end{array}$ & $\begin{array}{c}\mathrm{dO}_{2 \text { bio }} \\
\mu \mathrm{mol} \mathrm{kg}^{-1} \\
4\end{array}$ & $\begin{array}{c}\mathrm{dO}_{2 \text { air-sea }} \\
\mu \mathrm{mol} \mathrm{kg}{ }^{-1} \\
5\end{array}$ & $\begin{array}{c}\mathrm{NCP}_{\mathrm{C}} \\
\mathrm{mmolCm}^{-2} \mathrm{~d}^{-1} \\
6\end{array}$ & $\begin{array}{c}\mathrm{NCP}_{\mathrm{O}_{2}} \\
\mathrm{mmolO}_{2} \mathrm{~m}^{-2} \mathrm{~d}^{-1} \\
7\end{array}$ \\
\hline $18 \mathrm{Nov}$ & $-6.79 \pm 1.00$ & $-0.32 \pm 0.10$ & $10.23 \pm 1.35$ & $3.03 \pm 0.91$ & & \\
\hline 23-25 Nov & $-5.12 \pm 0.26$ & $-0.40 \pm 0.12$ & $5.83 \pm 0.83$ & $2.09 \pm 0.63$ & $-140 \pm 7$ & $120 \pm 23$ \\
\hline $23 \mathrm{Nov}$ & $-12.43 \pm 1.04$ & $-0.93 \pm 0.28$ & $14.18 \pm 1.66$ & $4.41 \pm 1.32$ & & \\
\hline $24 \mathrm{Nov}$ & $-10.47 \pm 1.00$ & $-0.38 \pm 0.11$ & $13.88 \pm 1.24$ & $2.47 \pm 0.74$ & & \\
\hline 26-28 Nov & $-4.50 \pm 0.85$ & $-0.28 \pm 0.09$ & $5.78 \pm 1.16$ & $1.87 \pm 0.56$ & $-124 \pm 23$ & $159 \pm 31$ \\
\hline $27 \mathrm{Nov}$ & $-9.74 \pm 1.01$ & $-0.39 \pm 0.12$ & $10.85 \pm 1.24$ & $2.46 \pm 0.74$ & & \\
\hline 30 Nov-4 Dec & $-2.20 \pm 0.45$ & $-0.44 \pm 0.13$ & $4.02 \pm 0.76$ & $2.31 \pm 0.69$ & $-60 \pm 12$ & $111 \pm 20$ \\
\hline $30 \mathrm{Nov}$ & $-9.07 \pm 1.01$ & $-0.58 \pm 0.17$ & $8.78 \pm 1.27$ & $2.60 \pm 0.78$ & & \\
\hline $1 \mathrm{Dec}$ & $-6.44 \pm 1.02$ & $-0.66 \pm 0.20$ & $9.78 \pm 1.57$ & $4.05 \pm 1.22$ & & \\
\hline 2 Dec & $-8.38 \pm 1.02$ & $-0.58 \pm 0.17$ & $10.88 \pm 1.48$ & $3.63 \pm 1.09$ & & \\
\hline 11-13 Dec & $-2.61 \pm 0.67$ & $-0.51 \pm 0.15$ & & $2.96 \pm 0.89$ & $-72 \pm 17$ & \\
\hline
\end{tabular}

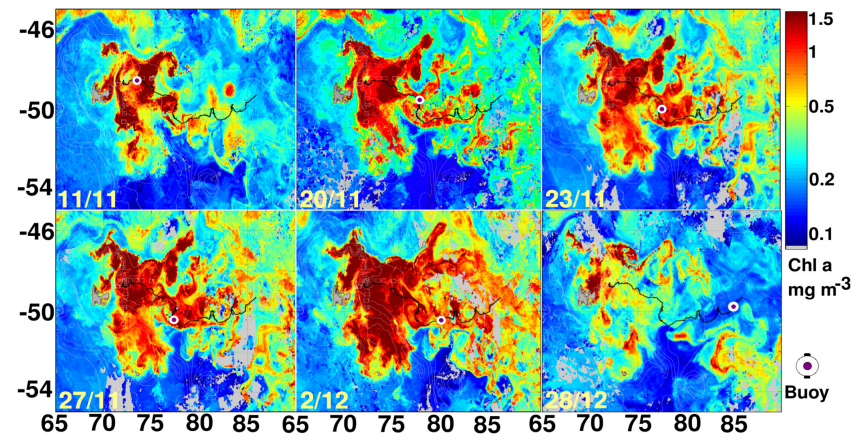

Figure 3. Spatial extent of phytoplankton blooms over and downstream from the Kerguelen Plateau as revealed by satellite ocean color on 6 selected days, between 11 November and 28 December 2011. The trajectory followed by the CARIOCA drifter is superposed on the chlorophyll patches (black line). The circles indicate the location of the buoy the same days.

\subsection{Chlorophyll and age distribution of the water parcels over and downstream the Kerguelen Plateau}

The time and spatial changes of the phytoplankton bloom as revealed by satellite ocean color are shown in Fig. 3 (on which the buoy trajectory is indicated). The strongest bloom is observed from 11 November to 2 December, about 2 months after bloom initiation, followed by a clear decay early summer in December.

The horizontal transport of water parcels eastward of the Kerguelen Plateau has been derived from altimetry (d'Ovidio et al., 2015). From this analysis, the time since a water parcel has left the plateau (the so-called age of the water parcel) could be estimated. The trajectory of the CARIOCA buoy was placed in this temporal framework using the age map of 25 November (Fig. 4). Over the period 1 November to 31 De-

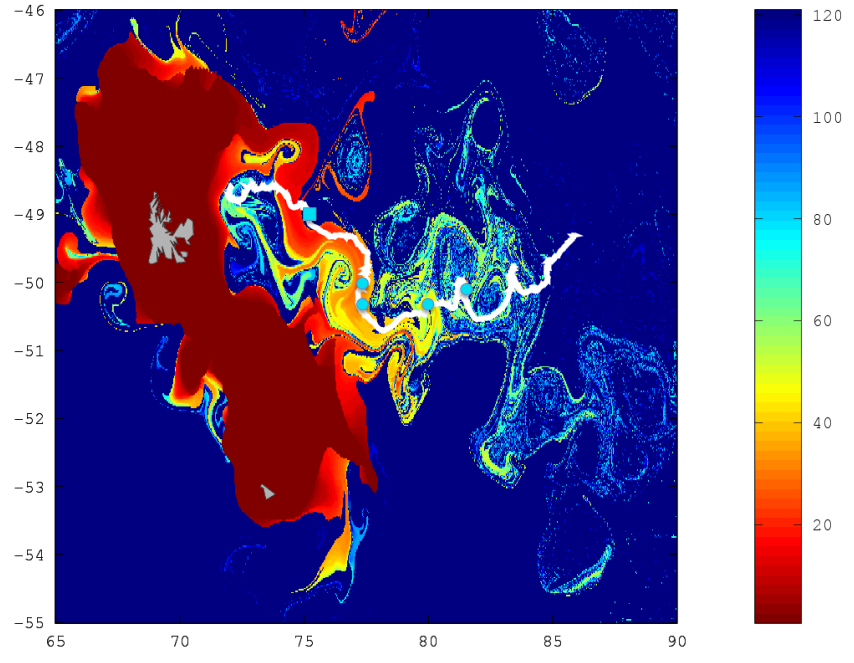

Figure 4. Lagrangian perspectives on large-scale natural iron fertilization on the Kerguelen Plateau and in the downstream plume: a snapshot on 25 November 2011. The color coding indicates the time in days since leaving the plateau for each water parcel (d'Ovidio et al., 2015). The white line indicates the trajectory of the CARIOCA drifter from 1 November to 31 December 2011. The cyan dots indicate the locations where carbon NCP estimates are calculated. The cyan square is the position of the buoy on 16 November (see text).

cember, the buoy sampled a large range of water parcels with different ages as shown by the stirring pathways east of the Kerguelen Plateau close to the trajectory of the drifter. NCP estimates have been made over the period 18 November13 December (Tables 1 and 2). 


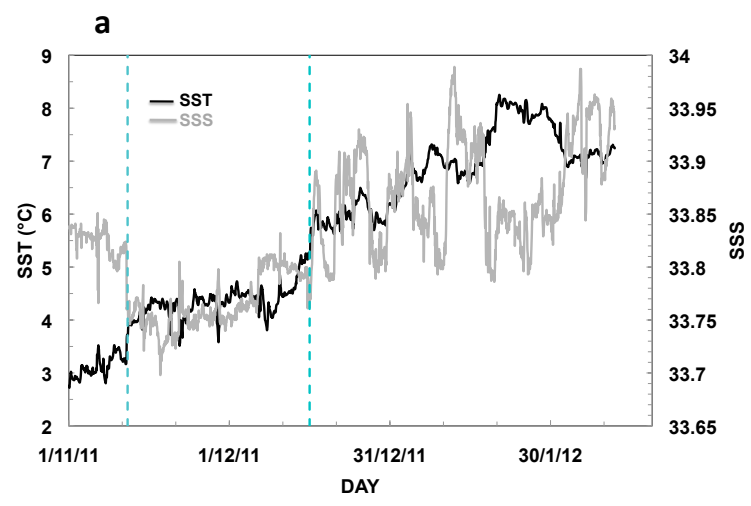

b
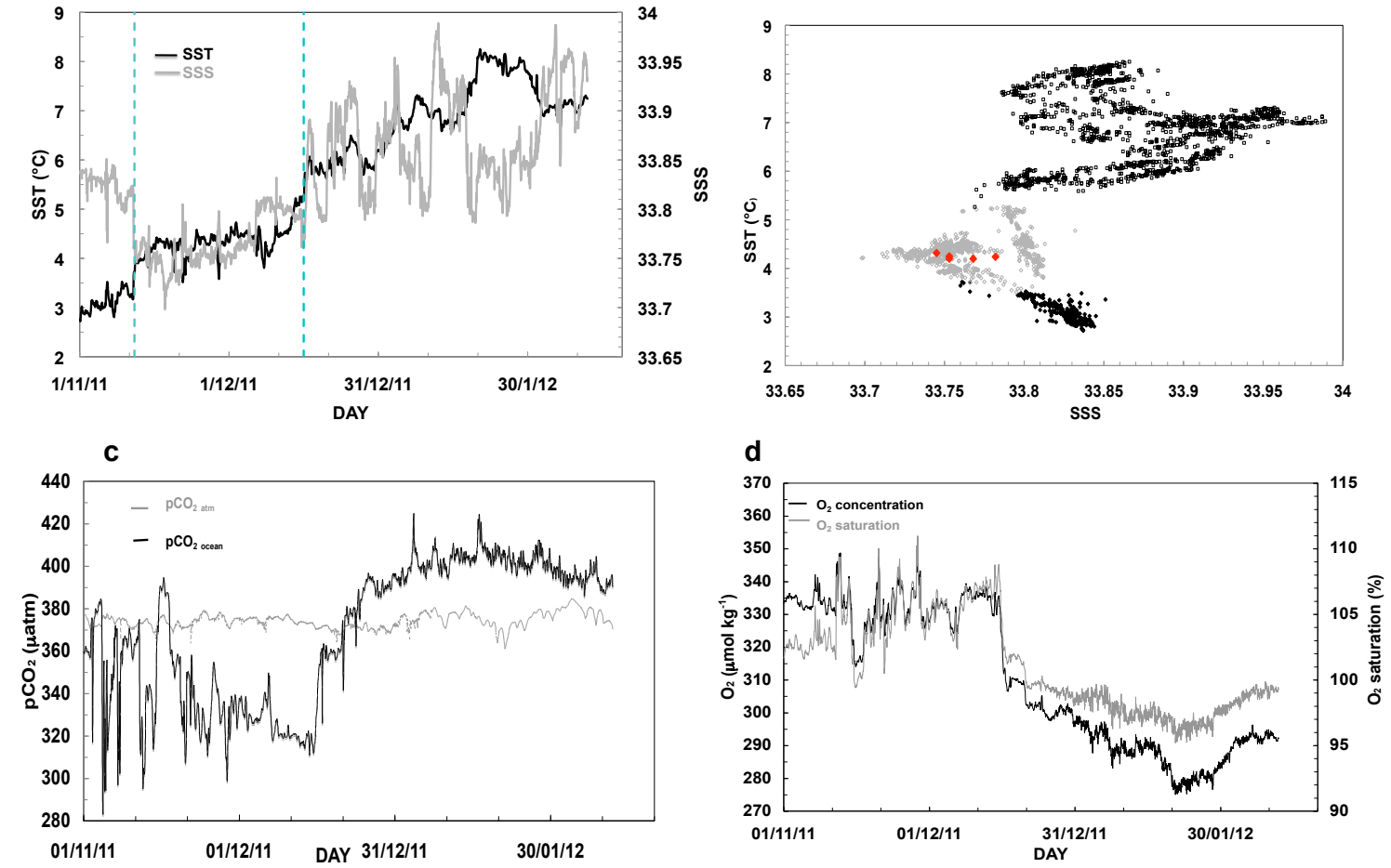

Figure 5. Buoy data from 1 November 2011 to 12 February 2012. (a) Temperature in ${ }^{\circ} \mathrm{C}$ (black, left vertical axis) and salinity (grey, right vertical axis). (b) Temperature-salinity diagram: 1 to 11 November, black diamonds; 12 November to 16 December, grey diamonds; 17 December to 12 February, black squares. (c) $p \mathrm{CO}_{2}$ measured at a depth of $2 \mathrm{~m}$ in $\mu$ atm (black) and in the atmosphere in $\mu$ atm (grey). (d) Dissolved oxygen concentration measured at a depth of $2 \mathrm{~m} \mathrm{in} \mu \mathrm{mol} \mathrm{kg}^{-1}$ (black, left vertical axis) and oxygen saturation in \% (grey, right vertical axis). In Fig. 5a, the cyan dashed lines indicate 12 November and 16 December (see text). In Fig. 5b, the red dots indicate the data measured at the KEOPS2 stations TEW7, TEW8, F-L.

\section{Results}

\subsection{Buoy measurements}

The variations of SST and SSS observed along the trajectory of the buoy are largely explained by its position relative to the polar front, PF (Fig. 1). From 1 to 12 November, the buoy was drifting in the meander of the PF (Park et al., 2014) with SST $\sim 3^{\circ} \mathrm{C}$ and $\mathrm{SSS} \sim 33.83$. From 12 November to 16 December, while the buoy followed closely and sometimes crossed the PF, SST was $\sim 4.2{ }^{\circ} \mathrm{C}$ and SSS $\sim 33.75$. During this time interval, simultaneous short time peaks of SST (negative) and SSS (positive) were observed while transiting the PF (Figs. 1 and 5a). From 16 December 2011 to 11 February 2012, the buoy drifted in the polar frontal zone, where higher temperature (close to $6^{\circ} \mathrm{C}$ ) and higher salinity (in the range 33.8 to 33.9 ) were measured.

A very large variability of $p \mathrm{CO}_{2}$ values, from $\sim 280$ to $\sim 400 \mu$ atm, were observed while the buoy drifted in the meander of the PF (Fig. 5c). Shipboard measurements of $p \mathrm{CO}_{2}$ made during the KEOPS2 field campaign show a similar range of variability (Lo Monaco et al., 2014). During periods when the buoy is southward or close to the PF, the surface waters were undersaturated in $\mathrm{CO}_{2}$ relative to atmospheric $\mathrm{CO}_{2}$. After 17 December, in the polar frontal zone, the surface waters became supersaturated. Moreover, the surface waters were supersaturated in oxygen up to 16 December, with saturation values up to $110 \%$ (Fig. 5d). In the polar frontal zone, data showed $\mathrm{O}_{2}$ undersaturation.

\subsection{Air-sea flux of $\mathrm{CO}_{2}$ and $\mathrm{O}_{2}$}

From 1 November to 17 December, surface waters are a source of $\mathrm{O}_{2}$ (Fig. 6a) for the atmosphere and a sink of $\mathrm{CO}_{2}$ (Fig. 6b). Conversely, in the polar frontal zone, east of $83^{\circ} \mathrm{E}$, we observe an ingassing of $\mathrm{O}_{2}$ and outgassing of $\mathrm{CO}_{2}$. It is worth noting that the absolute values of the fluxes are larger for $\mathrm{O}_{2}$ than for $\mathrm{CO}_{2}$ due to the buffer factor of ocean water carbonate chemistry. From 1 November to 16 December, the flux of $\mathrm{O}_{2}$ and $\mathrm{CO}_{2}$ are, respectively, $38 \pm 34$ and $-8.3 \pm 7.5 \mathrm{mmol} \mathrm{m}^{-2} \mathrm{~d}^{-1}$. After 16 December, they are equal, respectively, to $-48 \pm 43$ and $5.3 \pm 4.7 \mathrm{mmol} \mathrm{m}^{-2} \mathrm{~d}^{-1}$. 

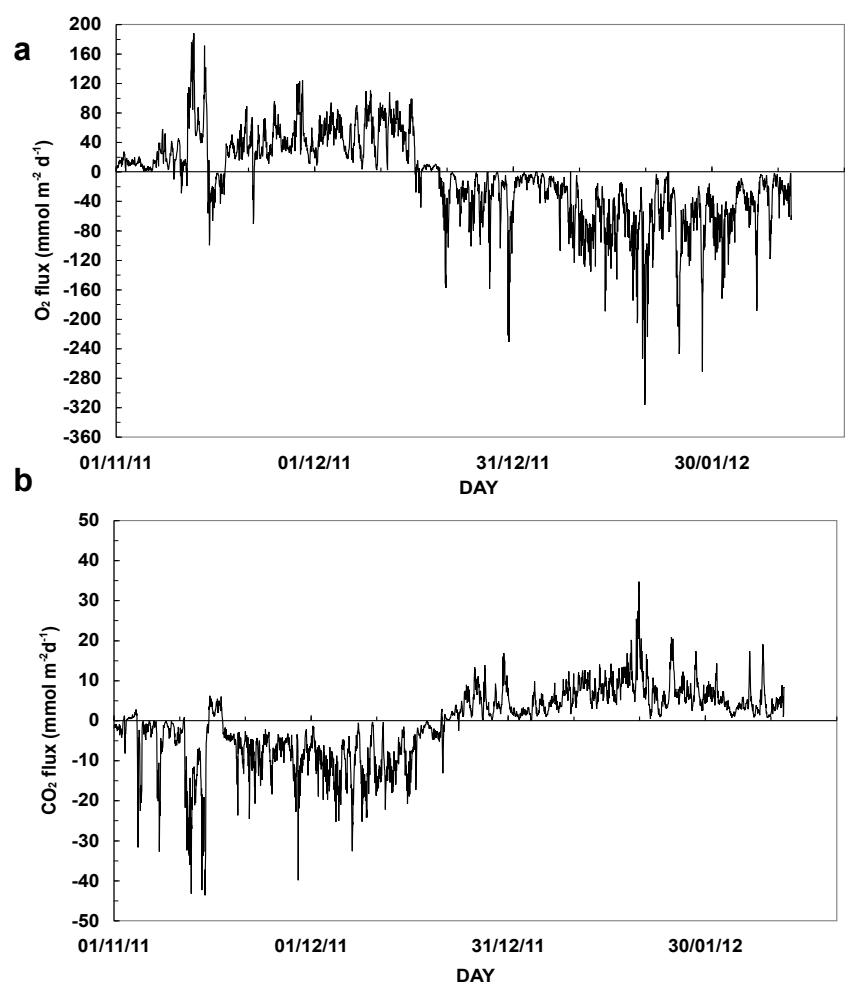

Figure 6. Air-sea flux from 1 November 2011 to 12 February 2012 in $\mathrm{mmol} \mathrm{m} \mathrm{m}^{-2} \mathrm{~d}^{-1}$ (positive for outgassing). (a) $\mathrm{O}_{2}$ ), (b) $\mathrm{CO}_{2}$.

\subsection{Dissolved inorganic carbon, DIC, and oxygen}

A significant reduction in DIC of $\sim 50 \mu \mathrm{mol} \mathrm{kg}{ }^{-1}$ is observed from 1 November to 17 December, followed by an increase of approximately $20 \mu \mathrm{mol} \mathrm{kg}{ }^{-1}$ when the buoy crossed the $\mathrm{PF}$ and starts drifting northward in the polar frontal zone. At the same time, a sharp decrease of the $\mathrm{O}_{2}$ concentration is measured (Fig. 7). During the first part of the trajectory of the buoy close to and along the PF, the highly variable distribution of the concentrations of DIC and $\mathrm{O}_{2}$ are controlled by physical transport processes, lateral advection and vertical mixing, air-sea exchange and biological processes. Four periods for DIC and $\mathrm{O}_{2}$ of 3 to 5 days have been identified when only air-sea exchange and biological processes control the change with time of the concentrations of DIC and $\mathrm{O}_{2}$, as described by Eqs. (6) and (7) (see also Fig. 2). For 7 days during these periods, the amplitude of the difference between the extrema $(|\max -\mathrm{min}|)$ for DIC and $\mathrm{O}_{2}$ in the warm daily surface layer, $h^{*}$, were measured (Table 1 and Fig. 8).

\subsection{Quantification of biological processes}

Large amplitudes of the diurnal cycles of DIC and $\mathrm{O}_{2}$ up to $12 \mu \mathrm{mol} \mathrm{kg}{ }^{-1}$ were measured, while day-to-day changes peak at $5 \mu \mathrm{mol} \mathrm{kg}{ }^{-1}$ (Fig. 8). These numbers represent the contribution of the biological processes plus the air-sea exchange terms (Eqs. 6 and 7). Their ratio is close to 1 (Fig. 8).

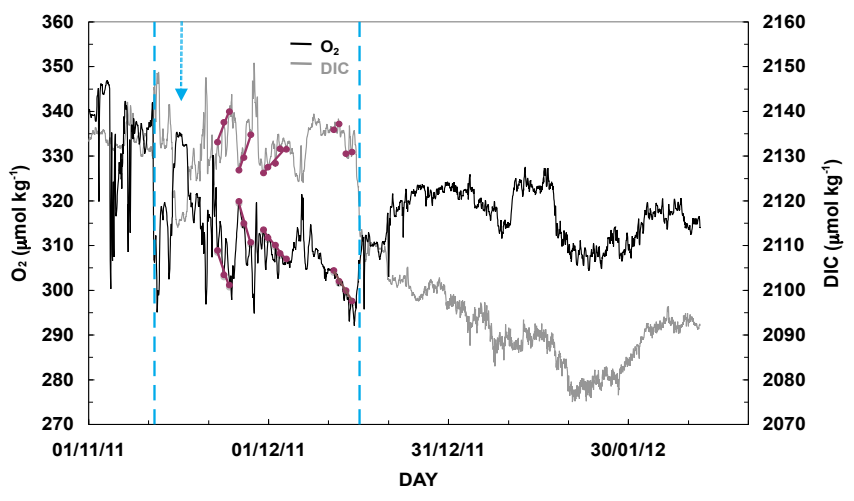

Figure 7. Distribution of $\mathrm{O}_{2}$ in $\mu \mathrm{mol} \mathrm{kg}{ }^{-1}$ (black, left vertical axis) and DIC in $\mu \mathrm{mol} \mathrm{kg}{ }^{-1}$ (grey, right vertical axis) between 1 November 2011 and 12 February 2012. The purple dots and lines indicate the periods when NCP estimates have been made. The cyan dashed lines indicate 12 November and 16 December and the cyan arrow 16 November (see text).

In Table 1, it is interesting to note the wide range of values of $\mathrm{CO}_{2}$ and $\mathrm{O}_{2}$ air-sea fluxes, the $\mathrm{O}_{2}$ fluxes up to 6.6 larger than the $\mathrm{CO}_{2}$ ones.

A summary of the biological and air-sea flux terms for DIC and $\mathrm{O}_{2}$ is given in Table 2. Figure 9 shows the simultaneous biological changes of $\mathrm{O}_{2}$ and DIC observed in the ten selected cases. The DIC measurements are used to calculate $\mathrm{NCP}_{\mathrm{C}}$ (Eq. 8 and Table 2). In November, two values of $\mathrm{NCP}_{\mathrm{C}}$, respectively equal to $140 \pm 7$ and $124 \pm 23 \mathrm{mmol}$ $\mathrm{C} \mathrm{m}^{-2} \mathrm{~d}^{-1}$, are computed. In December, we have $\mathrm{NCP}_{\mathrm{C}}$ equal to $60 \pm 12$ and $72 \pm 17 \mathrm{mmol} \mathrm{C} \mathrm{m}^{-2} \mathrm{~d}^{-1}$. The standard deviation does not include the uncertainty on the choice of the value of the MLD.

\section{Discussion}

\subsection{Hydrodynamical environment along the trajectory of the buoy}

During the 2011 KEOPS2 cruise, Park et al. (2014) determined and validated an up-to-date location of the PF around the Kerguelen Islands over the longitude of $78^{\circ} \mathrm{E}$. The PF, defined as the northern limit of the subsurface minimum of temperature, $T_{\min }$ of $2{ }^{\circ} \mathrm{C}$, was validated based on in situ hydrographic and current measurements made during the cruise, satellite ocean color images, and altimetry-derived surface velocity fields. The PF location rounds the Kerguelen Islands from the south, executing a permanent cyclonic meandering in the off-plateau area immediately east of the Kerguelen Islands and then extends eastward (Fig. 5, Park et al., 2014).

The buoy, after drifting inside the meander, traversed the front many times during which rapid increases of salinity were observed (Figs. 1 and 5). East of $78^{\circ} \mathrm{E}$, the compari- 


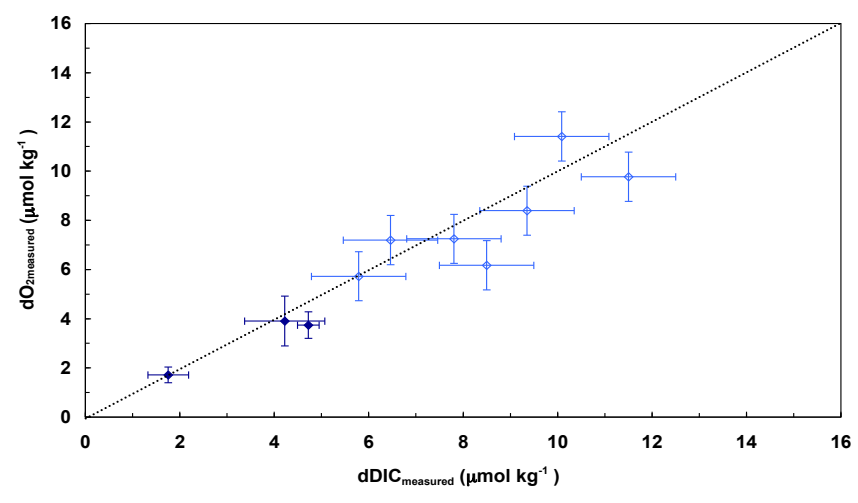

Figure 8. Measured changes (absolute values) of $\mathrm{O}_{2}\left(\mu \mathrm{mol} \mathrm{kg} \mathrm{kg}^{-1}\right)$ as a function of measured changes (absolute values) of DIC ( $\mu \mathrm{mol} \mathrm{kg}{ }^{-1}$ ) between consecutive mornings (dark blue dots) or during the daylight period (light blue dots). The slope of the black dotted line is 1 .

son of the two routes cannot be very specific as the trajectory of the buoy is compared with a large-scale climatological PF (Park et al., 2009, 2011) which certainly does not take into account the highly time-varying frontal circulation of the area. On 16 December, the latitude of the polar front as derived from the buoy measurements (Figs. 1 and 5) is very close to the climatological PF.

\subsection{Lagrangian distribution of chlorophyll along the trajectory of the buoy}

The sequence of ocean color images, to which the trajectory of the buoy from 11 November to 28 December is superposed (Fig. 3), shows the rapid development of the bloom until 2 December and then its decline. In most cases, the buoy follows the highly time-varying mesoscale meanders observed within satellite chlorophyll images. In their detailed study of the location of the PF during the KEOPS2 cruise, Park et al. (2014) put forward that the high-resolution chlorophyll concentration images appear as an excellent marker of the fronts and filaments, supporting evidence for the frontal circulation determined from the combined hydrography, altimetry and drifter tracking data. We are then led to conclude that the biological processes identified during four periods along the trajectory of the buoy (Fig. 1 and Table 1) are representative of frontal conditions which favor biological production. Specifically, the data computed between 18 and 28 November, in the longitude domain $76-78^{\circ} \mathrm{E}$, seem very tightly linked to the complex structures of the PF (Fig. 1).

In Fig. 4, the trajectory of the buoy is superposed on a mapping of the age of the water parcels since they have left the plateau where they are loaded with iron (d'Ovidio et al., 2015). The rate of change of the horizontal dissolved iron supply, DFe, downstream the plateau is modeled with an exponential decay of the initial on-plateau iron stock in the water column.

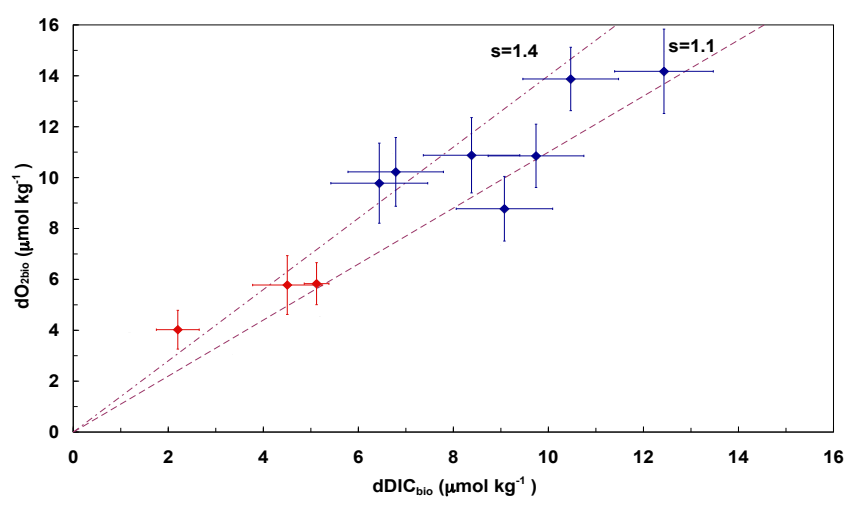

Figure 9. Changes (absolute values) of $\mathrm{O}_{2}\left(\mu \mathrm{mol} \mathrm{kg}{ }^{-1}\right)$ attributed to biological activity as a function of changes (absolute values) of DIC ( $\left.\mu \mathrm{mol} \mathrm{kg}{ }^{-1}\right)$ attributed to biological activity between consecutive mornings (red dots) or during the daylight period (blue dots). The two dotted lines with a slope of 1.4 and 1.1, respectively, characterize the new and regenerated production regime.

The data in Fig. 4 can be interpreted as representative of the changes of the stock of DFe in the ocean upper layer (0$150 \mathrm{~m}$ ), the largest DFe concentrations in the youngest waters. It is interesting to note, at least qualitatively, the relationship between the distribution of $\mathrm{DFe}$ and the signature of the biology on the DIC and $\mathrm{O}_{2}$ concentrations measured along the trajectory of the buoy. As a first example, when the buoy escaped the rich DFe waters on 15-16 November (the cyan square in Fig. 4), large abrupt changes of DIC (an increase) and $\mathrm{O}_{2}$ (a decrease) are observed (Fig. 7), suggesting the lack of organic matter production in the absence of iron.

\subsection{Carbon and oxygen biological production regimes}

During the KEOPS2 expedition, MLD were estimated at three stations (TEW-7, TEW-8, F-L) very close to the PF (Park et al., 2014) (Fig. 1). The average MLD at these stations, calculated with the criteria that depth where the potential density equals potential density at $10 \mathrm{~m}+0.02 \mathrm{~kg} \mathrm{~m}^{-3}$, was equal to $20 \mathrm{~m}$ (Park et al., 2014; Trull et al., 2015). We elect to use this depth as our MLD definition, as physical $(T, S)$ characteristics at these stations are very similar to CARIOCA measurements (Fig. 5b). Furthermore, the choice of a relatively shallow mixed layer, $20 \mathrm{~m}$, is supported by the work of Taylor and Ferrari (2012), who found, based on numerical simulations, that restratification at fronts can inhibit vertical mixing, triggering high-latitude phytoplankton blooms. However, the values of NCP integrated over the depth of the mixed layer may be an underestimate if the depth of the euphotic layer, Ze, is greater than MLD. During the KEOPS 2 expedition at the station F-L, Cavagna et al. (2014), indicate that $\mathrm{Ze}=30 \mathrm{~m}$. From the vertical profile of net primary production, NPP, based on the analysis of carbon-13 incubation experiments, the computed value of NPP integrated over $20 \mathrm{~m}$ represents about $75 \%$ of NPP in- 
tegrated over Ze. NPP at depth greater than Ze is negligible close to $2 \%$. We take into account an underestimation of $33 \%$ to compute NCP, as the euphotic layer depth is larger than the MLD which is equal to $20 \mathrm{~m}$.

The values of the carbon net community production, $\mathrm{NCP}_{\mathrm{C}}$, which corresponds to DIC transformed into particulate organic carbon, POC and dissolved organic carbon, DOC by biological activity, decrease from $130 \mathrm{mmol} \mathrm{m}^{-2} \mathrm{~d}^{-1}$ between 23 and 28 November to about $65 \mathrm{mmol} \mathrm{m}^{-2} \mathrm{~d}^{-1}$ at the beginning of December (Table 2). A similar range of values of carbon net community production along fronts in the Southern Ocean have previously been observed (Merlivat et al., 2015). During the KEOPS1 expedition in 2005, Lefèvre et al. (2008) and Jouandet et al. (2008) measured NCP at two stations south of the polar front. At the same locations, NCP measured at a 5-day interval varied between 105 and $43 \mathrm{mmol} \mathrm{C} \mathrm{m}^{-2} \mathrm{~d}^{-1}$. This illustrates the large spatial and temporal variability of processes which control NCP, depending on the bathymetry and the physical and dynamical regime prevailing in the upper layers in the KEOPS2 field study.

The biological terms, $\left(\frac{\Delta \mathrm{O}_{2}}{\Delta t}\right)_{\text {bio }}$ and $-\left(\frac{\Delta \mathrm{DIC}}{\Delta t}\right)_{\text {bio }}$ are represented in Fig. 9 on which the two lines with slopes equal to 1.4 and 1.1 indicate the expected oxygen-carbon relationship respectively for a new production regime, photosynthetic quotient, $\mathrm{PQ}=1.4$ or a regenerated one, $\mathrm{PQ}=1.1$ (Laws, 1991). During daytime, DIC and $\mathrm{O}_{2}$ variations represent GCP-R/2 (GCP, gross community production, $R$, respiration) if we assume the respiration rate to be constant over a day. From dawn to dawn, it corresponds to GCP-R. As a result, the daytime and the dawn-to-dawn ratio should be different, the difference being smaller when $R$ is small compare to GCP (autotrophy, high $f$ ratio). In Fig. 9 within the errors bars, we cannot estimate the difference. Nevertheless, it appears that both regimes may have prevailed at different times. This supports the choice of values of $h$ and $h^{*}$. With larger values of the MLD, the relative part of the air-sea flux in the DIC and $\mathrm{O}_{2}$ measurements would have been smaller and make the slope of the oxygen-carbon relationship closer to 1 as in Fig. 8. Further, the linear distribution of the data points (Fig. 9) demonstrates that our technique satisfactorily identifies the biological signature during the selected periods that we have considered.

In Table 2 (columns 3 and 5), we note the larger contribution of the air-sea exchange for oxygen (positive) relatively to carbon (negative), with a mean ratio of the absolute values close to 6 . In the calculation of $\mathrm{NCP}_{\mathrm{C}}$, the contribution of $\mathrm{CO}_{2}$ air-sea exchange is low, and varies between 7 and $25 \%$ of the measured change of DIC. By contrast, for oxygen, air-sea exchange represents 50 to $135 \%$ of the outgassing of $\mathrm{O}_{2}$ which results in a large uncertainty in the calculation of $\mathrm{NCP}_{\mathrm{O}_{2}}$. This situation occurs during observations made during the 11-13 December period, when it was not possible to isolate the oxygen biological signal due to the large air-sea flux.

This is an issue regarding the in situ estimates of NCP based on dissolved oxygen argon measurements at the ocean surface (Cassar et al., 2009) in high wind regions when the air-sea flux is large. NCP based on $\mathrm{O}_{2}$ measurements have to be considered with caution as long as the biological contribution is a small term relative to the air-sea exchange one.

Simultaneous measurements of oxygen and carbon ratios on oceanographic moorings have been reported in a few instances in tropical or mid-latitudes. Lefèvre and Merlivat (2012), based on data in the tropical Atlantic Ocean on a Pirata mooring equipped with a CARIOCA $p \mathrm{CO}_{2}$ sensor and an oxygen optode found an $\mathrm{O}_{2} /$ DIC ratio ranging between -1.0 and -1.3 .

Johnson (2010), using simultaneous measurements of $\mathrm{O}_{2}$ and DIC, at two moorings M1 and M2 off Monterey Bay, California, found $-0.77 \pm 0.02$ and $\pm 0.93 \pm 0.03$, respectively, for the $\mathrm{O}_{2} / \mathrm{TCO}_{2}$ ratio. He explains these low values with the different impact of gas exchange on DIC and $\mathrm{O}_{2}$, as the gas exchange for $\mathrm{O}_{2}$ is 10 times faster than for $\mathrm{CO}_{2}$. Martz et al. (2014) use autonomous oxygen and dissolved inorganic carbon observations to examine the oxygen carbon relationship at an upwelling site in the Southern California Current System. They compute a mean value of $\mathrm{O}_{2} / \mathrm{DIC}$ equal to $-1.20 \pm 0.01$ and conclude that it is in good agreement with Redfield ratio, in spite of a value different than the theoretical value of the Redfield ratio, 1.30.

We think that the distribution of our observed simultaneous biological changes of DIC and $\mathrm{O}_{2}$ (Fig. 9) convincingly exhibits a spectrum of values ranging from a near- $100 \%$ new production to a $100 \%$ regenerated production regime.

\subsection{Air-sea flux}

A striking feature is the abrupt change of the direction of the air-sea $\mathrm{CO}_{2}$ and $\mathrm{O}_{2}$ fluxes, from a sink of atmospheric $\mathrm{CO}_{2}$ at the ocean surface (the opposite for $\mathrm{O}_{2}$ ) to a source, on an episodic event on 16 November and 16 December when the buoy escaped the iron-fertilized plume to enter the polar frontal zone (Fig. 5). It illustrates how the carbon biological pump is at first order controlled by the iron availability in the water in the plume. These observations highlight the necessity to take into consideration the limits of the different water masses in order to spatially extrapolate field measurements of $\mathrm{CO}_{2}$ air-sea flux in a highly dynamic ocean area like the Southern Ocean. This is reinforced in an iron-fertilized region, as the distribution of the iron concentration is closely linked to this dynamic environment.

\section{Summary and conclusion}

Hourly $p \mathrm{CO}_{2}$ and oxygen measurements were made along the trajectory of a CARIOCA drifter downstream from the 
Kerguelen Plateau during the austral bloom from 1 November 2011 to 12 February 2012. From 1 November to 12 November, the buoy drifted through a cyclonic meander of the polar front and followed it eastward until 16 December, before heading north and entered the polar frontal zone. The surface water is supersaturated in oxygen until 16 December while $p \mathrm{CO}_{2}$ ocean is smaller than $p \mathrm{CO}_{2}$ atmosphere, suggesting that biological production dominates. North of the polar frontal zone, the ocean is a source of $\mathrm{CO}_{2}$ for the atmosphere and a sink of oxygen.

Using an alkalinity-salinity relationship, DIC is calculated from $p \mathrm{CO}_{2}$ and alkalinity. Net community production is calculated from changes of DIC and/or oxygen over short periods of time when biological activity is present and no mixing is encountered. NCP values obtained from 23 November to 13 December decrease from $140 \pm 7$ to $60 \pm 12 \mathrm{mmol}$ $\mathrm{C} \mathrm{m}^{-2} \mathrm{~d}^{-1}$. Concomitant $\mathrm{O}_{2}$ increases and DIC decreases allow the calculation of the oxygen carbon stoichiometric ratio $\mathrm{O}_{2} / \mathrm{C}$ in organic matter (dissolved and particulate) after subtracting the contribution of $\mathrm{CO}_{2}$ and $\mathrm{O}_{2}$ air-sea gas exchange. $\mathrm{O}_{2} / \mathrm{C}$ values range between 1.1 and 1.4 as expected for new and regenerated biological production regimes.

In the vicinity of the polar front, within the downstream Kerguelen Plateau plume, the absorbed $\mathrm{CO}_{2}$ air-sea flux is equal to $-8 \mathrm{mmol} \mathrm{m}^{-2} \mathrm{~d}^{-1}$ and the $\mathrm{O}_{2}$ outgassing equal to $+38 \mathrm{mmol} \mathrm{m}^{-2} \mathrm{~d}^{-1}$. In the polar frontal zone from $16 \mathrm{De}-$ cember 2011 to 12 February 2012, the ocean surface is a source of $\mathrm{CO}_{2}$ for the atmosphere equal to $+5 \mathrm{mmol} \mathrm{m}^{-2} \mathrm{~d}^{-1}$ and a sink for $\mathrm{O}_{2}$ equal to $-48 \mathrm{mmol} \mathrm{m}^{-2} \mathrm{~d}^{-1}$. The abrupt simultaneous changes of the sign of the air-sea $\mathrm{CO}_{2}$ and $\mathrm{O}_{2}$ fluxes when the buoy crosses the polar front show the dominant contribution of biology to the west in the iron-fertilized Kerguelen plume, which is characterized by an absorption of $\mathrm{CO}_{2}$ and an outgassing of $\mathrm{O}_{2}$. However a patchy distribution of iron within the plume can lead to a patchy organic carbon production and consequently affect the uptake of atmospheric $\mathrm{CO}_{2}$ unevenly in time and space. For instance, this is well illustrated when the buoy crosses the polar front on 16 December. This study points out that care should be taken when extrapolating sparse air-sea flux measurements observations without an understanding of the hydrodynamic features of the upper ocean.

Acknowledgements. We are grateful to N. Martin from LOCEAN for software development and to L. Beaumont from DT-INSU, who supervised the CARIOCA preparation. We thank S. Blain, project leader, and B. Quéguiner, chief scientist, as well as the captain and crew of R. R. V. Marion Dufresne and the staff at the French Polar Institute (IPEV), who provided logistic support. Special thanks to Claire Lo Monaco for access to $p \mathrm{CO}_{2}$ results and Dominique Lefèvre for access to $\mathrm{O}_{2}$ results. We thank Y. Park for having provided the data files for correctly positioning the polar front. We also enjoyed the stimulating discussions with N. Cassar during his stay at LOCEAN and the comments of S. Blain in the course of the preparation of the manuscript.
The research leading to these results was supported through EU FP6 project CARBOOCEAN (contract 511176) and EU FP7 project CARBOCHANGE "Changes in carbon uptake and emissions by oceans in a changing climate" which received funding from the European Commission's Seventh Framework Programme under grant agreement no. 264879. The KEOPS2 project was funded by the French institutes INSU (Institut National des Sciences de 1'Univers), IPEV (Institut Paul Emile Victor) and ANR (Agence Nationale de la Recherche).

Edited by: S. Blain

\section{References}

Blain, S., Quéguiner, B., Armand, L., Belviso, S., Bombled, B.,Bopp, L., Bowie, A., Brunet, C., Brussaard, C., Carlotti, F., Christaki, U., Corbière, A., Durand, I., Ebersbach, F., Fuda, J.L., Garcia, N., Gerringa, L., Griffiths, B., Guigue, C., Guillerm, C., Jacquet, S., Jeandel, C., Laan, P., Lefèvre, D., Lo Monaco, C., Malits, A., Mosseri, J., Obernosterer, I., Park, Y.-H., Picheral, M., Pondaven, P., Remenyi, T., Sandroni, V., Sarthou, G., Savoye, N., Scouarnec, L., Souhaut, M., Thuiller, D., Timmermans, K., Trull, T., Uitz, J., van Beek, P., Veldhuis, M., Vincent, D., Viollier, E., Vong, L., and Wagener, T.: Effect of natural iron fertilization on carbon sequestration in the Southern Ocean, Nature, 446, 10701074, 2007.

Blain, S., Sarthou, G., and Laan, P.: Distribution of dissolved iron during the natural iron fertilization experiment KEOPS (Kerguelen Plateau, Southern Ocean), Deep-Sea Res. Pt. II, 55, 594-605, 2008.

Borrione, I. and Schlitzer, R.: Distribution and recurrence of phytoplankton blooms around South Georgia, Southern Ocean, Biogeosciences, 10, 217-231, doi:10.5194/bg-10-217-2013, 2013.

Boutin, J. and Merlivat, L.: New in situ estimates of carbon biological production rates in the Southern Ocean from CARIOCA drifter measurements, Geophys. Res. Lett., 36, L13608, doi:10.1029/2009g1038307, 2009.

Boutin J., Merlivat L., Hénocq C., Martin N., and Sallée, J. B.: Air-sea $\mathrm{CO}_{2}$ flux variability in frontal regions of the Southern Ocean from CARIOCA drifters, Limnol. Oceanogr., 53, 20622079, 2008.

Boyd, P. W., Jickells, T., Law, C. S., Blain, S., Boyle, E. A., Buesseler, K. O., Coale, K. H., Cullen, J. J., de Baar, H. J. W., Follows, M., Harvey, M., Lancelot, C., Levasseur, M., Owens, N. P. J., Pollard, R., Rivkin, R. B., Sarmiento, J., Schoemann, V., Smetacek, V., Takeda, S., Tsuda, A., Turner, S., and Watson, A. J.: Mesoscale iron enrichment experiments 1993-2005: Synthesis and future directions, Science, 315, 612-617, 2007.

Cassar, N., Barnett, B. A., Bender, M. L., Hamme, R. C., and Tilbrook, B.: Continuous high frequency dissolved $\mathrm{O}_{2} / \mathrm{Ar}$ measurements by equilibrator inlet mass spectrometry, Anal. Chem., 81, 1855-1864, 2009.

Cavagna, A. J., Fripiat, F., Elskens, M., Dehairs, F., Mangion, P., Chirurgien, L., Closset, I., Lasbleiz, M., Flores-Leiva, L., Cardinal, D., Leblanc, K., Fernandez, C., Lefèvre, D., Oriol, L., and Quéguiner, B.: Biological productivity regime and associated N cycling in the surface waters over and downstream the Kergue- 
len Island area, Southern Ocean, Biogeosciences Discuss., 11, 18073-18104, doi:10.5194/bgd-11-18073-2014, 2014.

Copin-Montegut, C.: Consumption and production on scales of a few days of inorganic carbon, nitrate and oxygen by the planktonic community: results of continuous measurements at the Dyfamed Station in the northwestern Mediterranean Sea (May 1995), Deep-Sea Res. I, 47, 447-477, 2000.

Dickson, A. G. and Millero, F. J.: A comparison of the equilibrium constants for the dissociation of carbonic acid in seawater media, Deep-Sea Res., 34, 1733-1743, 1987.

Dickson, A. G., Sabine, C. L., and Christian, J. R.: Guide to Best Practices for Ocean $\mathrm{CO}_{2}$ Measurements, PICES Special Publication, 3191 pp., 2007.

d'Ovidio, F., Della Penna, A., Trull, T. W., Nencioli, F., Pujol, I., Rio, M. H., Park, Y.-H., Cotté, C., Zhou, M., and Blain, S.: The biogeochemical structuring role of horizontal stirring: Lagrangian perspectives on iron delivery downstream of the Kerguelen plateau, Biogeosciences Discuss., 12, 779-814, doi:10.5194/bgd-12-779-2015, 2015.

Friedlingstein, P., Cox, P., Betts, R., Bopp, L., Von Bloh, W., Brovkin, V., Cadule, P., Doney, S., Eby, M., Fung, I., Bala, G., John, J., Jones, C., Joos, F., Kato, T., Kawamiya, M., Knorr, W., Lindsay, L. K., Matthews, H. D., Raddatz, T., Rayner, P., Reick, C., Roeckner, E., Schnitzler, K.-G., Schnur, R., Strassmann, K., Weaver, A. J., Yoshikawa, C., and Zeng, N.: Climate-carbon cycle feedback analysis: Results from the (CMIP)-M-4 model intercomparison, J. Clim., 19, 3337-3353, 2006.

Garcia, H. E. and Gordon, L. I.: Oxygen solubility in seawater: better fitting equations, Limnol. Oceanogr., 37, 1307-1312, 1992.

Gruber, N., Gloor, M., Mikaloff Fletcher, S. E., Doney, S. C., Dutkiewicz, S., Follows, M. J., Gerber, M., Jacobson, A. R., Joos, F., Lindsay, K., Menemenlis, D., Mouchet, A., Müller, S. A., Sarmiento, J. L., and Takahashi, T.: Oceanic sources, sinks, and transport of atmospheric $\mathrm{CO}_{2}$, Global Biogeochem. Cy., 23, GB1005, doi:10.1029/2008GB003349, 2009.

Hood, E. M. and Merlivat, L.: Annual to interannual variations of $f \mathrm{CO}_{2}$ in the northwestern Mediterranean Sea: high frequency time series data from CARIOCA buoys (1995-1997), J. Mar. Res., 59, 113-131, 2001.

Johnson, K. S.: Simultaneous measurements of nitrate, oxygen, and carbon dioxide on oceanographic moorings: Observing the Redfield ratio in real time, Limnol. Oceanogr., 55, 615-627, 2010.

Jouandet, M. P., Blain, S., Metzl, N., Brunet, C., Trull, T. W., and Obernosterer, I.: A seasonal carbon budget for a naturally iron-fertilized bloom over the Kerguelen Plateau in the Southern Ocean, Deep-Sea Res. Pt. II, 55, 856-867, 2008.

Laws, E. A.: Photosynthetic quotients, new production and net community production in the open ocean, Deep-Sea Res., 38, 143167, 1991.

Lee, K., Tong, L. T., Millero, F. J., Sabine, C. L., Dickson, A. G., Goyet, C., Park, G. H., Wanninkhof, R., Feely, R. A., and Key, R. M.: Global relationships of total alkalinity with salinity and temperature in surface waters of the world's oceans, Geophys. Res. Lett., 33, L19605, doi:10.1029/2006GL027207, 2006.

Lefèvre, D., Guigue, C., and Obernosterer, I.: The metabolic balance at two contrasting sites in the Southern Ocean: The ironfertilized Kerguelen area and HNLC waters, Deep-Sea Res. Pt. II, 55, 766-776, 2008.
Lefèvre, N. and Merlivat, L.: Carbon and oxygen net community production in the eastern tropical Atlantic estimated from a moored buoy, Global Biogeochem. Cy., 26, GB1009, doi:10.1029/2010GB004018, 2012.

Lenton, A., Tilbrook, B., Law, R. M., Bakker, D., Doney, S. C., Gruber, N., Ishii, M., Hoppema, M., Lovenduski, N. S., Matear, R. J., McNeil, B. I., Metzl, N., Mikaloff Fletcher, S. E., Monteiro, P. M. S., Rödenbeck, C., Sweeney, C., and Takahashi, T.: Seaair $\mathrm{CO}_{2}$ fluxes in the Southern Ocean for the period 1990-2009, Biogeosciences, 10, 4037-4054, doi:10.5194/bg-10-4037-2013, 2013.

Le Quéré, C., Takahashi, T., Buitenhuis, E. T., Rodenbeck, C., and Sutherland, S.C.: Impact of climate change on the global oceanic sink of $\mathrm{CO}_{2}$, Global Biogeochem. Cy., 24, GB4007, doi:10.1029/2009GB003599, 2010.

Lo Monaco, C., Metzl, N., d'Ovidio, F., Llort, J., and Ridame, C.: Rapid establishment of the $\mathrm{CO}_{2}$ sink associated with Kerguelen's bloom observed during the KEOPS2/OISO20 cruise, Biogeosciences Discuss., 11, 17543-17578, doi:10.5194/bgd11-17543-2014, 2014.

Martz, T., Send, U., Ohman, M. D., Takeshita, Y., Bresnahan, P., Kim, H.-J., and Nam, S. H.: Dynamic variability of biogeochemical ratios in the Southern California Current System, Geophys. Res. Lett., 41, 2496-2501, doi:10.1002/2014GL059332, 2014.

Mehrbach, C., Culberson, C. H., Hawley, J. E., and Pytkowicz, R. M.: Measurement of the apparent dissociation constants of carbonic acid in seawater at atmospheric pressure, Limnol. Oceanogr., 18, 897-907, 1973.

Merlivat, L., Gonzales-Davila, M., Caniaux, G., Boutin, J., and Reverdin, G.: Mesoscale and diel to monthly variability of $\mathrm{CO}_{2}$ and carbon fluxes at the ocean surface in the northeastern Atlantic, J. Geophys. Res., 114, C03010, doi:10.1029/2007JC004657, 2009.

Merlivat, L., Boutin, J., and Antoine, D.: Roles of biological and physical processes in driving seasonal air-sea $\mathrm{CO}_{2}$ flux in the Southern Ocean: New insights from CARIOCA $p \mathrm{CO}_{2}$, J. Marine. Syst., 147, 9-20, doi:10.1016/j.jmarsys.2014.04.015, 2015.

Metzl, N., Tilbrook, B., and Poisson, A.: The annual $f \mathrm{CO}_{2}$ cycle and the air-sea $\mathrm{CO}_{2}$ flux in the sub-Antarctic Ocean, Tellus B, 51, 849-861, 1999.

Park, Y.-H. and Vivier, F.: Circulation and hydrography over the Kerguelen Plateau, in The Kerguelen Plateau: marine ecosystem and fisheries, edited by: Duhamel, G. and Welsford, D., 597 pp., Cybium, Paris, 2011.

Park, Y.-H., Vivier, F., Roquet, F., and Kestenare, E.: Direct observations of the ACC transport across the Kerguelen Plateau, Geophys. Res. Lett., 36, L18603, doi:10.1029/2009GL039617, 2009.

Park, Y.-H., Durand, I., Kestenare, E., Rougier, G., Zhou, M., d'Ovidio, F., Cotté, C., and Lee, J.-H.: Polar Front around the Kerguelen Islands: An up-to-date determination and associated circulation of surface/subsurface waters, J. Geophys. Res., 119, 6575-6592, doi:10.1002/2014JC010061, 2014.

Pollard, R. T., Salter, I., Sanders, R. J., Lucas, M. I., Moore, C. M., Mills, R. A., Statham, P. J., Allen, J. T., Baker, A. R., Bakker, D. C. E., Charette, M. A., Fielding, S., Fones, G. R., French, M., Hickman, A. E., Holland, R. J., Hughes, J. A., Jickells, T. D., Lampitt, R. S., Morris, P. J., Nedelec, F. H., Nielsdottir, M., Planquette, H., Popova, E. E., Poulton, A. J., Read, J. F., Seeyave, S., Smith, T., Stinchcombe, M., Taylor, S., Thomalla, S., Ven- 
ables, H. J., Williamson, R., and Zubkov, M. V.: Southern Ocean deep-water carbon export enhanced by natural iron fertilization, Nature, 457, 577-580, 2009.

Sweeney, C., Gloor, E., Jacobson, A. R., Key, R. M., McKinley, G., Sarmiento, J. L., and Wanninkhof, R.: Constraining global air-sea gas exchange for $\mathrm{CO}_{2}$ with recent bomb ${ }^{14} \mathrm{C}$ measurements, Global Biogeochem. Cy., 21, GB2015, doi:10.1029/2006GB002784, 2007.

Takahashi, T., Sutherland, S. C., Wanninkhof, R., Sweeney, C., Feely, R. A., Chipman, D. W., Hales, B., Friederich, G., Chavez, F., Sabine, C., Watson, A., Bakker, D. C. E., Schuster, U., Metzl, N., Yoshikawa-Inoue, H., Ishii, M., Midorikawa, T., Nojiri, Y., Körtzinger, A., Steinhoff, T., Hoppema, M., Olafsson, J., Arnarson, T. S., Tilbrook, B., Johannessen, T., Olsen, A., Bellerby, R., Wong, C. S., Delille, B., Bates, N. R., and de Baar, H. J. W.: Climatological mean and decadal change in surface ocean $p \mathrm{CO}_{2}$, and net sea-air $\mathrm{CO}_{2}$ flux over the global oceans, Deep-Sea Res. Pt. II, 56, 554-577, 2009.

Taylor, J. R. and Ferrari, R.: Ocean fronts trigger high latitude phytoplankton blooms, Geophys. Res. Lett., 38, L23601, doi:10.1029/2011GL049312, 2011.
Trull, T. W., Davies, D. M., Dehairs, F., Cavagna, A. J., Lasbleiz, M., Laurenceau, E. C., d'Ovidio, F., Planchon, F., Leblanc, K., Quéguiner, B., and Blain, S.: Chemometric perspectives on plankton community responses to natural iron fertilization over and downstream of the Kerguelen plateau in the Southern Ocean, Biogeosciences 12, 1029-1056, doi:10.5194/bg-12-1029-2015, 2015.

Wanninkhof, R. H.: Relationship between wind speed and gas exchange over the ocean, J. Geophys. Res., 97, 7373-7382, 1992.

Weiss, R. F.: $\mathrm{CO}_{2}$ in water and seawater: the solubility of a nonideal gas, Mar. Chem., 2, 203-215, 1974.

Weiss, R. F. and Price, B. A.: Nitrous oxide solubility in water and seawater, Mar. Chem., 8, 347-359, doi:10.1016/03044203(80)90024-9, 1980.

Woolf, D. K. and Thorpe, S. A.: Bubbles and the air-sea exchange of gases in near-saturation conditions, J. Mar. Res., 49, 435-466, 1991. 